\title{
EDUCATION
}

(C) 2019 Boyko. This article is distributed under the terms of CC Attribution-Share Alike 4.0 International described at https://creative commons.org/licenses/by-sa/4.0

\author{
UDC: 37.017:502[504](477+73)
}

\section{GREEN CULTURE ASSESSMENT OF THE AMERICAN AND UKRAINIAN HIGH SCHOOL STUDENTS AS FUTURE CITIZENS}

\author{
Yakiv Boyko \\ PhD in Education, \\ Pavlo Tychyna Uman State University, Uman, Ukraine \\ https://orcid.org/0000-0001-5672-396X; e-mail: yakivboyko@meta.ua
}

The article deals with the levels of Green Culture of the American and Ukrainian High School students including three components: cognitive and process skills, value and motivation, action and behavior. In the situation of numerous researches in this field, the study is intended to analyse the key components of Green Culture in Ukraine and the USA. The high school in this analysis was targeted because students are future citizens of their countries and their level of proficiency in environmental literacy is a clear indicator of future trends in handling of environmental issues. The author also took into consideration the fact that students of two countries have different levels of Green Culture. In the USA teachers try to focus not purely on knowledge, but on its practical implementation and developing process skills of students. In Ukraine the high level of attention to environmental knowledge transition to students testifies to a more theoretical approach within educational system.

Application of the innovative USA experience is considered by the author as the most productive way to improve the environmental education in the high school in Ukraine. Based on the findings of the research the author developed the recommendations for the Ukrainian school taking into consideration the specific features of the American experience in.

The recommendations comprise the peculiarities of the role of a family, participation, the use of basic principles of environmental education, the core content or recommended themes and topics, interdisciplinary approach, instructional techniques, ICT, global, national, regional and local perspectives.

Key words: environmentally responsible behavior, Green Culture, environmental education, environmental attitude, environmental information, process skills, nature protection. 
У статті характеризуються різні рівні сформованості екологічної культури учнів старших класіВ у сучасній середній школі США та Украйни. НезВажаючи на численні дослідження $b$ чій галузі, вказана проблема залишається не повністю розкритою. У статті проаналізовано критерії сформованості екологічної культури старшокласників: когнітивно-аналітичний, ціннісно-мотивачійний і діяльісно-поведінковий.

Учні стариих класів стануть незабаром громадянами своєї крайни, $а$ рівень їх екологічної грамотності є чітким показником майбутніх тенденцій В даній сорері. Ми також врахуъали той фракт, щзо учні циих двох крайн мають різний рівень екологічної культури. В американсъкому підході вчителі намагаються зосередити увагу не лише на кониептуальному $і$ фоктичному вивченню, а формуванню діяьнісних та науково-прочесуальнх навичок. В украйнсъких школярів високий рівень екологічних знань свідчить про більш теоретичний підхід у закладах загальної середнъої освіти.

Найкращий $і$ найпродуктивніший спосіб покращити формування екологічної культури у Вітчизняній системі екологічного виховання школярів - ие ВикористовуВати деякі поради та кроки, які вже вивченні та розроблені $b$ США. На основі проведених досліджень розроблено деякі рекомендачії. Перед впровадженням будь-якої рекомендачії щзодо вдосконалення екологічної осъіти в Україні необхідно враховувати особливості вітчизняної виховної практики. Кількість рекомендачій не є остаточною і може бути оновлена 3 часом. Такі рекомендації включають відведення важливої ролі сім'ї, підвищення ступеня оволодіння практичними екологічними навичками, Використання міждисциплінарного підходу, IKT, методичних розробок та рекомендованих тем тощо.

Ключові слова: заклад загальної середнъої освіти, екологічна культура, екологічна освіта, могічне мислення, підлітки, США, учні старших класів, екологічна грамотність.

Introduction. Ukraine is a party to many International Environmental Agreements and is moving towards the American and international integration that implies the unification of economic, legislative and political policies between different countries. Therefore, it means that an educational aspect is considered while dealing with them. Young people should become environmental stewards and be engaged into rational actions in handling of nature issues. Such cooperation between countries can perform a function of further improvement of the Ukrainian environmental education curriculum in terms of the theory and practice.

It is important to mention valuable American experience that is worth integrating into the environmental school policy in Ukraine. The American experience offers high school students a dynamic learning that encourages critical thinking, develops problem-solving skills, and nurtures their intellectual and social development necessary for successful acceptance of responsibility for their actions and learning to uphold the necessary values in their future life. 
Humans continue to demonstrate environmentally unfriendly behaviors at the individual, corporate, governmental, and societal levels. Concern for environmental issues that surfaced in the 1960's is still dominating now. Such situation requires environmental education programs to be provided in schools. Moreover, the lack of its distinct place in the curriculum is one of the major drawbacks of school environmenttal education. In the USA, the educators try to solve this problem using interdisciplinary approach or by integrating project-based learning in schools. There is a lot of advantages of such integration: multicultural education, real world application, cooperative learning, empowerment, interdisciplinary topics, problem-solving, con-text for the application of different subjects and scientific principles, exploration of attitudes and values, engagement of students with different learning styles, hands-on activities and close ties with the community. These advantages can make ecology very compelling to teachers. But how to evaluate and assess such advantages? The first thing to do is to construct an instrument for measuring such changes. In our survey, we tried to see the differences between the Green Culture of American and Ukrainian High School students. Our goal was to make components of Green Culture informative and present not only qualitative but also quantitative research findings.

The term «Green Culture» and its first appearance in the academic literature are subject to discussion. It seems to be a disagreement about who did use or attempted to define the term for the first time. In general, many Ukrainian researchers defined it as a part of a general culture of a personality (I. Pavlenko, G. Gorbulich, 2008; N. Poustovit, 2014).

Very often, the term «Green Culture» is associated with its synonym, which is «environmentally literate» that means a desired outcome of environmental education. The «environmentalism», «conservation» and «sustainability» are other related terms. Summarizing the findings of the studies of the American and the Ukrainian scholars in this field, we consider the Green Culture to be an integrated construct that includes environmental literacy, ability to foresee the consequences of environmental activities, process skills, environmental stewardship, action skills and strategies.

In fact, we consider the Green Culture to be a complex process. It means consistent influence of ideology, law, science, industry, art and education. Further, it is based on environmental education and related to the promotion of a culture of sustainability among younger generation.

Despite different models of Green Culture in both countries, we tried to identify the common components. The US researchers tend to gather environmental education data based on such factors as awareness and sensitivity, knowledge and understanding, attitudes, skills, participation. Hines, et al (1986) developed an Environmental Behavior Model and differentiated between the following components as cognitive knowledge of environmental issues, cognitive knowledge of action skills and action strategies and personality factors. While the Ukrainian ones mostly concentrate on knowledge, affective domain and behavior.

Our objective is to assess Green Culture of the American and Ukrainian High school students according to some criteria. The second objective is to compare and comment on above-mentioned results. And the last one implies setting up recommendations to promote the positive US environmental education ideas in Ukraine. 
For the past 15 years, a new generation of foreign environmental education scholars have created innovative approaches and ideas (Bosschaart, Adwin, 2016; Dubois, Bryce \& Krasny, Marianne E., 2016; Gough, Annette, 2017; Kopnina, Helen, 2014; Liefländer, Anne Kristin \& Bogner, Franz Xaver, 2014; Meeusen, Cecil, 2014; Ojala, Maria, 2015; Payne, Phillip G., 2016; Russ, Alex, 2015; Stanišić, Jelena \& Maksić, Slavica, 2014; Vreede, Catherine de, Warner, Alan \& Pitter, Robert, 2014).

The environmental education issues have been studied by the following postsoviet researchers (S. Hlazachev, Y. Kogai, 1999; I. Pavlenko, G. Gorbulich, 2008; B. Likhachev, 1998; N. Poustovit, 2014; A. Pyrina, 2006; S. Sovhira, 2013).

Methodology. The current teaching and learning structure for fostering Green Culture of High School is different in the Ukrainian and American scientific literature. It has very often conflicting views, but most researchers agree that during this age special attention should be paid to cognitive and behavioral goals and objectives. The level of affective domain is also crucial in High school.

We limited the number of components of Green culture by selecting only three of them: environmental knowledge and process skills, affective domain and motivation, environmental behavior and actions. This was necessary to ensure our commitment and simplify the procedure of gathering survey data as well as make it easier to process it. Certainly, the sample clearly cannot be considered completely representative of Green Culture and its limitedness suggests being cautious while generalizing from this research.

We differentiate between the following indicators of Green Culture:

1. Cognitive and process component which includes knowledge and concepts of environmental issues, understanding the positive and negative human impact on our environment, realizing the causes of environmental crisis in local and global communities, familiarity with the general laws of nature coexistence of humans, animals and plants, the rules of ethical conduct in nature and process component.

2. Value and motivation component which implies a love to nature, positive attitudes towards our environment and its conservation, concern, commitment and interest in environmental issues, recognizing the need to take environmental actions in the community, personal involvement in finding solutions to global environmental problems, motivation in dealing with the problems related to the interaction between man and nature.

3. The action and behavioral component: environmental monitoring, participation in environmental actions and organizations, environmental projects, spreading environmental awareness among schools and general public, identification of priories in environmental policy and find best solutions to it, anticipating the implication of the consequences of your actions and decisions, experience in taking appropriate actions.

Based on the points of Green Culture components we differentiate between the following levels of Green Culture: high, sufficient, satisfactory and elementary.

High level can be found in students who have a proficient level of knowledge and understanding of the nature and environmental problems, able to engage in responsible environmental behavior in a productive manner, have deep understandding of human place in nature, an expression of love for nature and independent 
thinking. Also, High school students are actively involved in environmental activities, and this can be explained by willingness, motivation that are based on personal beliefs and norms of society.

Sufficient level is very common with the students, who show a sufficient level of knowledge about basic ecological concepts as well as positive and negative human impact on the environment; understand the causes of environmental crisis in the world, aware of nature general laws of humans, animals and plants coexistence in ecosystem, use ethical behavior. Moreover, students show their love for nature, have awareness and understanding of human place in ecosystem; sometimes participate in environmental activities as a result of their response to certain stimuli.

Satisfactory level is typical for high school students, who show a satisfactory level of knowledge about basic environmental concepts as well as of positive and negative human impact on the environment, not fully understand the causes of environmental crisis in the world, have superficial acquaintance with the nature general laws of humans, animals and plants, have satisfactory knowledge of the rules of ethical behavior in our environment. Such students show their love for nature only to some degree, characterized by weak awareness of nature and humans in it; seldom participate in environmental projects and actions.

Elementary level is widespread among high school students who have no understanding of basic environmental concepts as well as of positive and negative human impact on the environment, do not realize the causes of modern environmental crisis in the world, have a low awareness of ecosystem and its elements such as human beings, animals and plants, have poor knowledge of the rules of ethical behavior in nature. Additionally, students show indifference to environmental issues, they have no love for nature, they do not see any importance of nature in human life; do not take any part in environmental activities.

In Ukraine, the study of levels of Green Culture among High school students was carried out in schools of Cherkasy Region (Uman schools 1, 5, 9 and in Uman district). The research methodology of this study involved teacher interviews, review of related literature, discussion with a panel of scientists, class observations, examination of materials and standards in Ukraine and the USA. The survey to assess Green Culture of High school students was conducted by the students of Foreign Languages Department of Uman State Pedagogical University named after Paul Tychyna who underwent training in the USA camps. Additionally, the students of Uman University have been involved into international student exchange programs since 1997. The Ukrainian exchange students measured the level of Green Culture of American young people. More than 161 responders from Ukraine and 186 responders from the USA took part in our study. The total number of responders involved into the survey was 347 (186 responders from Ukraine and 161 responders from the USA: New York, Virginia, California, North Carolina, Minnesota and Massachusetts).

Results. In our survey, we found the following trends in Green Culture among the Ukrainian and USA students. In this study we found statistically significant differences among the above-mentioned groups regarding the levels of knowledge and process skills, attitude and values, action skills and behavior. Thus, the 
American and Ukrainian high school students are characterized by different amount of Green Culture points. Particularly it is evident in environmental knowledge. The high level of environmental knowledge of the Ukrainian students can be explained by a more theoretical approach in the educational system. However, they did not score more points in attitude and value factor as well as in participation domain. In American approach, teachers try to focus not so much on knowledge, but on its practical implementation and developing process skills. In other words, knowledge acquired in a practical way. The result of such interaction can be found in social behavior, close relations with the community and developing action skills.

\section{Table 1. Different levels of Green Culture of American and Ukrainian High School Students}

\begin{tabular}{|c|c|c|c|c|c|c|c|c|}
\hline \multirow{3}{*}{ Components } & \multicolumn{8}{|c|}{ The levels of Green Culture } \\
\hline & \multicolumn{4}{|c|}{$\begin{array}{c}\text { United States } \\
\text { High School Students (186) }\end{array}$} & \multicolumn{4}{|c|}{$\begin{array}{c}\text { Ukrainian } \\
\text { High School Students (161) }\end{array}$} \\
\hline & 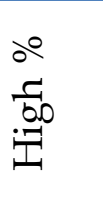 & 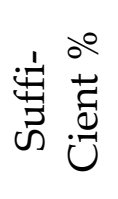 & 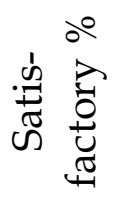 & 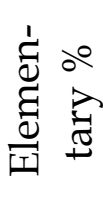 & 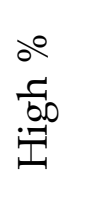 & 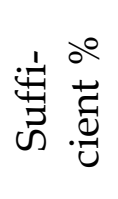 & 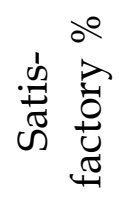 & 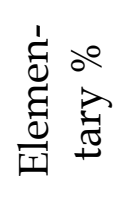 \\
\hline $\begin{array}{l}\text { Value and } \\
\text { motivation } \\
\text { component }\end{array}$ & 68,0 & 25,4 & 4,3 & 2,3 & 55 & 27,6 & 12,0 & 5,4 \\
\hline $\begin{array}{l}\text { Cognitive } \\
\text { and process } \\
\text { component }\end{array}$ & 52,1 & 19,0 & 15,2 & 3,7 & 57,4 & 21,0 & 17,4 & 6,2 \\
\hline $\begin{array}{l}\text { The action and } \\
\text { behavioral } \\
\text { component }\end{array}$ & 62,3 & 20,7 & 14,6 & 2,4 & 51,0 & 17,7 & 17,5 & 3,8 \\
\hline Total: & 60,8 & 21,7 & 11,7 & 2,8 & 54,5 & 22,1 & 15,6 & 5,1 \\
\hline
\end{tabular}

The results of this study showed that there is a serious gap between environmental education in the USA and Ukraine. Therefore, here are some of the recommendations, which are worth implementing into the Ukrainian High School education:

1. The powerful domestic influences of families on children's environmental engagement are either ignored or not fully considered in the curriculum development of the Ukrainian schools. During early stages, family has an impact on a child development and his/her socialization. Parents support the consolidation and embedding of beliefs, attitudes, and values. Children that conform and obey the norms and rules is the purpose of any family. Firstly, they must internalize the social norms and values that dictate what is normal or abnormal. Secondly, children must sociallize and become future citizens under the guidance of their parents. In Ukraine, there are many educational programs and courses aimed at increasing and enhancing the environmental literacy of parents. All this leads to improved knowledge, responsible 
and informed action, commitment to environmental protection and sustainability, better understanding of teaching strategies etc. In addition, close ties should be developed between school and parents as well as community. Such understanding of fostering environmental education and bringing up children makes it very valuable and should be implemented in Ukrainian school system where it is not so widespread and parental involvement is considered to be an add-up or something extra.

2. Next, only a productive understanding and informed decisions can lead to responsible behavior and constructive action toward the environment. Further, environmental education is heavily dependent upon action. Providing environmental awareness, knowledge and attitude differs from simply developing action skills. Most experts argue that knowledge and attitude are closely related to behavior. Though knowledge and understanding play an important role in developing the responsible environmental behavior, sometimes it may not lead to desirable actions and consequences. It is inseparable from any school educational process where the ability to engage in responsible environmental behavior is important. One of the main goals is to produce initiative and action in Ukrainian High schools. Without a doubt, many experts agree that ability to grasp the ecological concepts and principles isn't simply enough. Nowadays green culture can be characterized by willingness to act on learned materiel. Sometimes it is not easy to combine theoretical and practical approaches. Certainly, there is always a gap between them. School practical activity usually has nothing to do with the theoretical study in the classroom. There are many reasons of it. On the one hand, some the Ukrainian teachers have no confidence and experience in dealing with environmental problems and identifying local fauna and flora. On the other hand, it is not easy to evaluate students' performance. Similarly, there is a group of teachers who claim they don't have proper facilities and are not willing to interfere with changes in school timetable and organizational issues involved. In addition to this, lack of time, access, funding, professional development, knowledge, administration and interest are the most common obstacles. However, in order to handle the problem of field learning and practical lessons we must concentrate on valuable American experience of solving such issues and more environmental projects should be conducted in high schools.

3. The interdisciplinary approach, lifelong learning, action and practical skills, interdependence with other peoples, other species and the planet as a whole, moving from awareness to knowledge and to action, incorporating harmony of humans and nature, developing a personal or emotional bond with nature, future-oriented strategy, incorporating media literacy into every school subject, role modeling for their students and facilitating student's learning and promoting integrity of local, regionnal, national and international approaches are among the basic principles of environmental education. The Ukrainian list of environmental principles is not full and can benefit from the American experience.

4. In order to develop environmental literate citizens, teachers should meet the core content, which includes the following themes: Ecological history, Fundamentals of Ecology, Human Ecology, Evolution, Ethics of Ecology, Environmental Behavior, Urban Ecology and other related topics (Eulefeld, 1976, p. 200). Besides, special attention should be paid to process skills. As a rule, topics and issues that can be 
addressed are resource conservation, water resources, energy conservation, climate change, resource consumption, alternative energy, biodiversity, sustainable agriculture, air quality and others. Ukrainian teachers should focus more on recommended themes and topics while considering process skills and environmental behavior.

5. Legal Authority for Environmental and Sustainability Education already exists in Washington State. It says about Mandatory Areas of Study in the Common School. «Instruction about conservation, natural resources, and the environment shall be provided at all grade levels in an interdisciplinary manner through science, the social studies, the humanities, and other appropriate areas with an emphasis on solving the problems of human adaptation to the environment».

The school day is already full. Therefore, American teachers are suggesting that they integrate environmental education into the subjects in the school curriculum. It can save time and cover environmental content, skills for problem-solving, context for exploring attitudes and values, multicultural education, real world application, cooperative learning, empowerment and process skills. Such advantages are very compelling to teachers.

Sustainable Design or environmental projects can be successfully integrated into current teaching. In the USA, it is a means of completing students' culminating project graduation requirement. Students design solutions to such issues as climate change, sustainable food, resource conversation, clean air and others. Such projects aim at students' researching and their designing solutions within the context of sustainability and nature preservation. In such interdisciplinary approach, students can connect with the core subjects, identify a problem in a real-world context and work effectively individually or in teams. As a result, curriculum integration can provide support to schools in integrating environmental education and green culture and be a meaningful context for core content areas.

Ukrainian school system can incorporate interdisciplinary integration and make environmental education a part of the curriculum without stealing time from other subjects.

6. Lacks of global, national, regional and local perspectives are concerns for the American educators. Many environmental challenges are not limited by boundaries of their countries and become concerns of the international level. Students of high school should think and act globally. Examples of theoretical classes can be found in the local community or even in other countries, at national or international levels. Moreover, the combination of such approaches is very useful in the treatment of environmental issues. Such limitations to the proposed strategies can cause serious setbacks in teaching and understanding about the natural environment. Such perspectives imply changes in the content of science and social disciplines as well as in textbooks.

Thus, Ukrainian teachers found a lack of global, national, regional and local perspectives in schools. Ukrainian teachers consider such obstacles in teaching ecology and environmental science to be very important and substantial but there is still little recognition of it. Indeed, students require a shift in their perspectives. 
7. A fundamental change should be made in instructional methods. Absolutely, the Ukrainian teachers are supposed to use combinations of many strategies and methods for obtaining effective teaching. Certainly, American educators and experts have accumulated some experience. It implies the ability to select teaching methods, paying attention to learning styles, for better students`engagement and process skills development. At the present time some Ukrainian teachers misunderstand these techniques. They should play a more active role in social and political matters of their country. The main goal of environmental education and Green Culture is to develop problem solving skills of environmental issues, use inquiry, sustainable design projects, lab experimentation, debate and discussion, demonstration, investigation, lecture, role-playing, implement excursions and field trips into the environmental curriculum etc. Such educational technologies can give a chance to a child to evaluate, understand and observe.

To remove the obstacles, the Ukrainian teachers should attend in-service environmental education workshops, programs, courses that help them to gain experience of different instructional methods and prepare them for future teaching assignments.

8. In general, the goal of most environmental organizations is to aid in the mission for everyone to become more aware on how to become sustainable and put it into practice. Moreover, their mission of environmental organizations is to generate programs that promote an informed and engaged public, better poised to become involved and make changes to support climate resilience efforts locally, regionally, nationally, and globally. Though there are many ways to teach environmental literacy with the help of different teaching resources that cover a range of key science and biology subjects (they may contain classroom presentations, activities and handouts as well as more practical and sustainable projects), participation in green movements and political parties gives students and their parents a very unique experience. Most US high schools support the idea of sustainability and environmental protection through practical engagement and close partnership with environ-mental organizations. For example, there are a number of a nonprofit organization that promotes locally grown food and organic farms, has created a new curriculum to help educate high school students and their parents about organic farming and gardening. Also, the maturation of the environmental movement and organizations that contribute to high school environmental education is one of the USA characteristic features and is seen in the increase of their number, size and funding for the last decade. Overall, Ukrainian educational policy lacks most of this features that's why environmental organizations are not so closely linked to high school and its curriculum.

9. Obviously, we cannot imagine our life without computer knowledge and skills. Professional development of teachers in information and communication technologies is very useful and essential while planning their professional life. It helps to provide a framework for professional development of staff in schools. According to UNESCO research (UNESCO, 2002), «Circumstances and resources vary markedly between countries, all of which will impact on the implementation of any new ICT curriculum and will affect how educational systems cope with change» (p. 12). In order to develop ICT curriculum, we must take into consideration these 
variations between countries, schools and facilities. Environmental curriculum and ICT go hand in hand because students spend so much time on locating and exchanging information, processing data, using supporting computer software and identifying a presentation forum for their sustainable design projects.

In both developed and developing countries studies of ICT development identify at least four broad approaches, termed emerging, applying, infusing, and transforming, through which educational systems and individual schools proceed in their adoption and use of ICT and represents a continuum or ongoing process (UNESCO, 2002). In Ukraine, some schools demonstrate Emerging approach, where they provide some computing equipment and software to support environmental curriculum and educational process. Of course, introduction of new environmental and ICT curriculum implies careful preparation, management, resourcing, and continuing support. Naturally, many educators have agreed that the teaching of ICT causes difficulties and poses some problems. Certainly, efficiency of environmental education is connected to digital technologies because both of them are used as a context for real world application and are integrated in all subjects in an interdisciplinary manner. In most cases, numerous obstacles are not only of financial concern but also of administrative nature. In other words, such schools need not only computing equipment and software but also awareness and willingness of administrative staff to integrate such changes in the curriculum.

Discussion. The findings of this research are based upon empirical data and have been collected by students of Uman University during their practice in the USA. We tried to assess the level of high school environmental education according to some criteria in Ukraine and the USA and developed the above-mentioned recommendations. Though we did our best to figure out some of the steps, which can positively influence our high school education, there are new tendencies that already exist in the USA. Obviously, they will play a crucial role and impact our society in the decade ahead. One of them is the extensive use of innovative technologies such as computers, laptops, Wi-Fi, interactive boards, new educational programs. Many of the researches are not sure about the impact ICT will produce on our community in 10 years' time. But the consequences are rather obvious. They will completely change the role of the communities, teachers, students and the way they cooperate. For example, there are already virtual expeditions that will be widely engaged into the system of education in the next years to come. Though our recommendations might be fruitful if they are introduced in Ukraine, they are not complete.

The USA has already accumulated substantial experience in this field. For this reason, we concentrated on the United States of America. Truly, there is a huge gap in terms of financial income between Ukraine and the USA. There is a lot of information to consider before choosing this or that recommendation. Not much information is provided regarding costs involved in such researches to improve Ukrainian green culture. In most cases such problems arise when our educators cannot fully implement them due to financial challenges they face. It is not always easy to make a budget and accumulate the proper financial funds for certain actions and tools. Additionally, parents, families, educators and communities should not wait passively and should take responsibility for the learning process of their children. 
Conclusions. Thus, based on the findings relating different levels of the Green Culture of the American and Ukrainian High School students we can made some conclusions. A clear trend of fostering Green Culture in the American schools can be seen. In particular, the American youth scored more points in value and motivation component than their Ukrainian counterparts (68\% and 55\% respectively). Concurrently, the Ukrainian teachers emphasized the cognitive domain over affective, behavioral and value components. This can be explained by the fact that the Ukrainian subject teachers apparently shared a notion that behavior arises from knowledge rather from values, motivation and affective domain.

Today the goal of teachers is to prepare students for solving real world problems while using curriculum integration. This implies that ICT is a tool that helps students to be more successful in environmental and sustainable curriculum. Consequently, students can easily search and retrieve information on environmental issues and problems and participate in nature conservation. Easy access to information concerning ecosystem and nature directly affects the successful integration of environmental education, students' career development and involvement. In this regard, in recent years in the United States there is an increased attention of schools to online applications, portals and multimedia platforms dedicated to environmental issues, where contests and creative environmental projects are announced regularly.

To conclude, despite huge differences between the Ukrainian and USA environmental education, we can use and integrate most of the American valuable experience to make the national environmental curriculum more efficient. Considering all the above recommendations, it is imperative to implement them into Ukrainian school curriculum.

\section{References:}

Altman, I. (1980). Culture and environment. Cambridge: University Press.

Bosschaart, Adwin, Schee, Joop van der \& Kuiper, Wilmad. (2016). Designing a flood-risk education program in the Netherlands. The Journal of Environmental Education, 47(4), 271-286. Retrieved from: http://www.tandfonline.com/doi/full/10.1080/00958964.2015.1130013.

Dubois, Bryce \& Krasny, Marianne E. (2016). Educating with resilience in mind: Addressing climate change in post-Sandy New York City. The Journal of Environmental Education, 47(4), 255-270. Retrieved from: http://www.tandfonline.com/doi/full/10.1080/00958964.2016.1167004.

Edward W. Warren, Gary E. Marchant. (1993). More Good Than Harm: A First Principle for Environmental Agencies and Reviewing Courts. Ecology Law Quarterly, 20(3). Retrieved from: http://scholar ship.law. berkeley.edu/cgi/viewcontent.cgi?article=1441\&context=elq.

Eulefeld, G. (1976). An ecological approach to restructuring school biology. Journal of Biological Education, 10 (14), 196-202.

Gough, Annette. (2011). The Australianness of Curriculum Jigsaws: Where Does Environmental Education Fit? Australian Journal of Environmental Education, 27(1), 9-23. Retrieved from: http:// www.aaee.org.au/wp-content/uploads2/2008/11/AJEE_27_1_2011_Special_Issue-1.pdf.

Gough, Annette, Russell, Constance and Whitehouse, Hilary. (2017). Moving gender from margin to center in environmental education. The Journal of Environmental Education, 48(1), 5-9. Retrieved from: http://www.tandfonline.com/doi/full/10.1080/00958964.2016.1252306.

Hines, J. M., Hungerford, H. R. and Tomera, A. N. (1986) An analysis and synthesis of research on responsible environmental behavior. Journal of Environmental Education, 18 (2), 1-8.

Kopnina, Helen. (2014). Future Scenarios and Environmental Education. The Journal of Environmental Education, 45(4), 217-231. Retrieved from: http://www.tandfonline.com/doi/full/10.1080/ 00958964.2014 .941783$. 
Liefländer, Anne Kristin \& Bogner, Franz Xaver. (2014). The Effects of Children's Age and Sex on Acquiring Pro-Environmental Attitudes Through Environmental Education. The Journal of Environ-mental Education, 45(2), 105-117. Retrieved from: http://www.tandfonline.com/doi/ full/10.1080/0095 8964.2013.875511.

Mcphie, Jamie, Clarke, David Andrew George. (2015). A Walk in the Park: Considering Practice for Outdoor Environmental Education Through an Immanent Take on the Material Turn. The Journal of Environmental Education, 46(4), 230-250.

Meeusen, Cecil. (2014). The Intergenerational Transmission of Environmental Concern: The Influence of Parents and Communication Patterns Within the Family. The Journal of Environmental Education, 45(2), 77-90. Retrieved from: http://www.tandfonline.com/doi/full/10.1080/ 00958964.2013 .846290 .

Melnick, S. (1983). Regulation and the Courts: The case of the Clean Air Act. Washington, DC: Brookings Institution.

Ojala, Maria. (2015). Hope in the face of climate change: associations with environmental engagement and student perceptions of teachers' emotion communication style and future orientation. The Journal of Environmental Education, 46(3), 133-148. Retrieved from: http://www.tandfonline. com/doi/full/10.1080/00958964.2015.1021662?scroll=top\&needAccess=true.

Payne, Phillip G. (2016). What next? Post-critical materialisms in environmental education. The Journal of Environmental Education, 47(2), 169-178. Retrieved from: http://www.tandfonline.com/doi/ full/10.1080/ 00958964.2015.1127201.

Review draft report on Washinghton State K-12 Environmental Education and Education for Sustain-ability 2008 Teacher Survey (September, 2008). Office of Superintendent of Public Instruction, Washington. Gilda Wheeler, Abby Ruskey, Colleen Uuereb. Retrieved from: http://www.k12.wa.us/en vironmentsustainability/pubdocs/EE-EFSSurveyReport.pdf.

Russ, Alex. (2015). Development of Ecological Place Meaning in New York City. The Journal of Environmental Education, 46(2), 73-93. Retrieved from: http://www.tandfonline.com/doi/full/10.1080/ 009589642014.999743?scroll=top\&needAccess=true.

Sovgira, Svitlana, Goncharenko, Ganna, Lavryk, Oleksandr. (2008). Sanitary health areas of middle city territory. "Economics for Ecology» ISCS'2008, 14th International Student Conference, Sumy, Ukraine, 177-179. Retrieved from: http://s3.amazonaws.com/academia.edu.documents/310133 68/ISCS_Materials_2008.pdf?AWSAccessKeyId=AKIAIWOWYYGZ2Y53UL3A\&Expires=14919 06386\&Signature $=$ BV4URFEtFGHbhoGNOXbzAXFP32s\%3D\&response-content-disposition $=$ in line\%3B\%20filename\%3DEnvi ronment_and_technology_use_of_innova.pdf\#page=176.

Stanišić, Jelena \& Maksić, Slavica. (2014). Environmental Education in Serbian Primary Schools: Challenges and Changes in Curriculum, Pedagogy, and Teacher Training. The Journal of Environmental Education, 45(2), 118-131. Retrieved from: http://www.tandfonline.com/doi/full/10. 1080/00958964. 2013.829019.

Stevenson, Robert B. (2011). Sense of Place in Australian Environmental Education Research: Distinctive, Missing or Displaced? Australian Journal of Environmental Education, 27(1), 46-55. Retrieved from: http://www.aaee.org.au/wp-content/uploads2/2008/11/AJEE_27_1_2011_ Special_Issue-1.pdf.

United Nations Educational, Scientific and Cultural Organization. Information and communication technology in education (2002). A curriculum for schools and Programme of teacher development Retrieved from: http:// unesdoc.unesco.org/images/0012/001295/129538e.pdf.

Vreede, Catherine de, Warner, Alan \& Pitter, Robert. (2014). Facilitating Youth to Take Sustainability Actions: The Potential of Peer Education. The Journal of Environmental Education, 45(1), 37-56. Retrieved from: http://www.tandfonline.com/doi/full/10.1080/00958964.2013.805710.

Warner, Benjamin P., Elser, Monica. (2015). How Do Sustainable Schools Integrate Sustainability Education? An Assessment of Certified Sustainable K-12 Schools in the United States. The Journal of Environmental Education, 46(1), 1-22. 